\title{
ECONOMIC AND SOCIO-CULTURAL DRIVERS OF NECESSITY AND OPPORTUNITY ENTREPRENEURSHIP DEPENDING ON THE BUSINESS CYCLE PHASE
}

\author{
Isabel MARTÍNEZ-RODRIGUEZ (D) ${ }^{*}$, Fernando E. CALLEJAS-ALBIÑANA (D)2, \\ Ana Isabel CALLEJAS-ALBIÑANA (D) 3 \\ 1, 2 Department of Spanish and International Economic, Econometrics and Economic \\ History, Faculty of Law and Social Sciences, University of Castilla-La Mancha, \\ Ciudad Real, Spain \\ ${ }^{3}$ Department of Psychology, Faculty of Education, University of Castilla-La Mancha, \\ Ciudad Real, Spain
}

Received 30 November 2018; accepted 14 November 2019

\begin{abstract}
This paper offers an in-depth examination of the behavior of necessity- and opportunitydriven entrepreneurship. First, it considers their relevance to total entrepreneurial activity. It then seeks to determine which socio-cultural and economic factors affect the two types of entrepreneurship, as well as their relative importance for a sample of 32 previously selected countries during a period of expansion (2001-2008) and of crisis and recovery (2009-2016). The analyzed factors include monetary and fiscal policy instruments (economic factors) and representative variables of governance and human capital (socio-cultural ones). The findings show that both necessity- and opportunity-driven entrepreneurship largely explain the behavior of total entrepreneurial activity. They moreover show that the explanatory factors of both kinds of entrepreneurship differ depending on the business cycle phase considered. These findings will be key to proposing efficient economic policy measures to promote entrepreneurial activity and, thus, economic growth in different economies around the world.
\end{abstract}

Keywords: entrepreneurship, opportunity, necessity, socio-cultural factors, economic factors, economic growth, business cycle, GEM.

JEL Classification: C23, E32, J23.

\section{Introduction}

Entrepreneurship is recognized as a source of economic growth and employment creation. As a result, many policy makers throughout the world explicitly pursue policies that are aimed at increasing the amount of entrepreneurship (Acs et al., 2017; Fotopoulos \& Storey, 2019).

^Corresponding author. E-mail: isabel.mrodriguez@uclm.es 
Likewise, individuals are increasingly attracted by the option of becoming entrepreneurs, whether motivated because they have no other job options and need a source of income (necessity) or by the perception that there is a business opportunity that has not yet been taken advantage of (or has been taken advantage of only incompletely) by existing companies (opportunity) (Peña et al., 2014, p. 55).

This research aims to analyze the behavior of entrepreneurial activity, differentiating between necessity and opportunity entrepreneurship. First, it will seek to determine whether these types of entrepreneurship are the most representative of total entrepreneurial activity and, therefore, explain its behavior. Second, it will seek to identify the most influential social and economic factors in the behavior of each type of entrepreneurship, analyzing whether they vary depending on the moment of the business cycle, i.e. expansion $(2001-2008)^{1}$ or crisis and recovery (2009-2016). GEM data from the 32 most representative countries was selected for each type of entrepreneurship to obtain valid conclusions for more national economies.

To achieve these objectives, Section 1 will examine entrepreneurship as a key topic in the economic literature and the center of economic policy, where it has recently become a priority objective for the governments of the world's leading emerging and advanced economies due to the causal link between long-term economic growth and entrepreneurial activity. It will then review the literature on some of the key social and economic factors driving necessity and opportunity entrepreneurship. Section 2 will estimate various econometric models using the panel data method. The models are run using a sample group of countries and variables considered to be the most characteristic of both necessity and opportunity entrepreneurship. The aim is to identify which factors are determinant for each situation so as subsequently to propose efficient economic policy measures to promote entrepreneurship in each particular case. This is relevant because of the necessity of works that refine the measures of entrepreneurship at national level and develop methodologies that enable close scrutiny of particular effects (Du \& O’Connor, 2018, p. 107).

\section{Theorical framework and hypothesis development}

Entrepreneurship has currently become a priority objective of the governments of the world's leading emerging and advanced economies, due to its positive impact on employment (Thurik et al., 2008; Halicioglu \& Yolac, 2015; Akinyemi et al., 2018) and economic growth (Acs, 2006; Acs et al., 2017; Meyer \& De Jongh, 2018; Urbano et al., 2019). The original factors, identified by Solow (1956) and Swan (1956), such as capital, labor, and productivity, together with more recent additions by Lucas (1988) and Romer (1986) in their endogenous growth theory such as human capital, innovation, knowledge, have been joined by entrepreneurial activity (Carree \& Thurik, 2003; Urbano \& Aparicio, 2016).

For a correct design of policies aimed at promoting entrepreneurship, it is important to identify which factors affect their activity and how they do so. In addition to the economic

\footnotetext{
${ }^{1}$ Although the start of the financial and economic crisis can be traced to the summer of 2007, the effects of the financial crisis became noticeable after a delay, in 2009. The pre-crisis period, from 1999 to 2008, was a period of growth favorable to entrepreneurship (Bonnet et al., 2015).
} 
factors, it is important to consider those social and cultural factors that are increasingly becoming more and more important in the design of policies (Thornton et al., 2011; Pandit et al., 2018; Walsh \& Winsor, 2019). At the same time, it is fundamental to consider if the entrepreneur is moved by necessity or by opportunity, and the impact of business cycle (Fairlie \& Fossen, 2018). Overall, this research aims to explore entrepreneurial activity based on an integrative approach using all the previous elements to contribute to the difficult task of efficient design of policies that promote entrepreneurship (Figure 1).

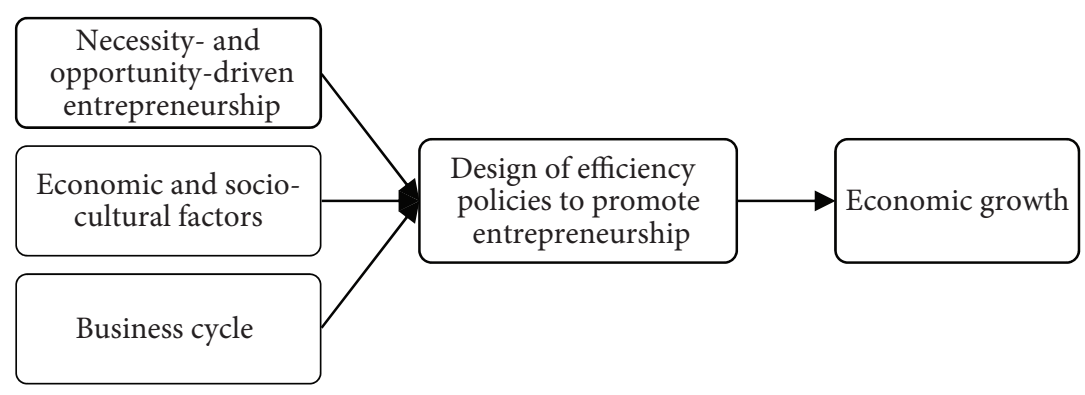

Figure 1. Research model

\subsection{Necessity (NTEA) versus Opportunity (OTEA) entrepreneurship}

The Global Entrepreneurship Monitor (GEM) project is used to analyse entrepreneurship. Since 1997, this research consortium collects cross-national data on numerous aspects of entrepreneurship aggregated at the country level, providing indicators on entrepreneurial activity, attitudes and aspirations (Angulo-Guerrero et al., 2017). Currently, GEM has gained widespread recognition as the most authoritative longitudinal study of entrepreneurship in the world and is widely used by academics and practitioners (Amorós \& Bosma, 2014).

This paper analyzes the motivation to become an entrepreneur distinguishing between two different types of entrepreneurship identified by GEM, namely opportunity and necessity entrepreneurship. Although GEM recognizes the existence of other secondary motivations that can influence the decision to become an entrepreneur (De la Vega, 2008), GEM considers that both entrepreneurship by necessity and by opportunity are the main ones and, therefore, those that explain to a greater extent the Total Entrepreneurial Activity (TEA) (Reynolds et al., 2002; Block \& Wagner, 2010).

Necessity-driven entrepreneurs are pushed to start businesses because they have no other job options and need a source of income (Peña et al., 2014, p. 55). They largely arise as a result of purely economic motivations (Block \& Sandner, 2009; van der Zwan \& Hessels, 2013) but they may also be motivated by occupational safety concerns (Tyszka et al., 2011, p. 129) or their own professional or personal dissatisfaction (Noorderhaven et al., 2004).

Opportunity-driven entrepreneurs, on the other hand, choose to start or create a business based on the perception that there is a business opportunity that has not yet been taken advantage of (or has been taken advantage of only incompletely) by existing companies (Peña et al., 2014, p. 55). They are generally driven by both economic motivations (Carter et al., 
2003; Cassar, 2007) and non-economic ones such as the need for independence and achievement (Tyszka et al., 2011, p. 129) or the aspiration to create their own business, be their own boss, and develop new products (Cassar, 2007).

The both distinct motivations, opportunity and necessity entrepreneurship, have been repeatedly discussed and contrasted with each other in the literature (Fairlie \& Fossen, 2018; Caliendo \& Kritikos, 2019; Mota et al., 2019). This paper aims to progress the study of entrepreneurship and complete the theorical and empirical research carried out so far analyzing the entrepreneurial behavior by necessity and opportunity to be able to design efficient policies that promote total entrepreneurial activity. Hence, the following hypothesis is proposed:

H1: Necessity- and opportunity-driven entrepreneurship explain total entrepreneurial activity.

\subsection{Economic and socio-cultural factors affecting necessity and opportunity entrepreneurship}

Studies on entrepreneurship have primarily focused on the role of economic factors (Noorderhaven et al., 2004) giving limited attention the influence of socio-cultural context (for exceptions see Shapero \& Sokol, 1982; Gnyawali \& Fogel, 1994; Thornton et al., 2011). Thus, this research intends to take a further step in the analysis of entrepreneurship through the consideration of decisive economic and sociocultural factors. Although both the economic and socio-cultural factors are determinant to total entrepreneurial activity, they do not affect both NTEA and OTEA equally, as their motivations and particularities for each type are different. To design efficient policies that encourage entrepreneurship, it is important to specify which factor is most influential in each type in order to apply the appropriate instruments.

First, access to credit is particularly important for nascent and growing firms (Bassetto et al., 2015), therefore, the application of expansive monetary policies focused on facilitating access to financing are key to facilitate and encourage entrepreneurship. It must be considered that, when monetary policy is restrictive, the banking sector's response affects companies disproportionately depending on their size (Gaiotti \& Generale, 2001; Bougheas et al., 2006; Lawrenz \& Oberndorfer, 2018) due to their access to alternative sources of financing to bank credit (Ma et al., 2019). Specifically, it causes banks to change their credit offer in favor of large companies to the detriment of small ones (Gertler \& Gilchrist, 1994; Back \& Rosen, 2011). Accordingly, a monetary restriction could be more worrisome for NTEA, who tend to be linked to small companies, with low income levels (Block \& Wagner, 2010) and lower growth expectations (Poschke, 2013). Aware of the difficulties they face to access credit, necessity-driven entrepreneurs are likely to choose to prioritize alternative sources of financing, such as informal money from family and friends or public subsidies since, coming from unemployment, they are often ideal candidates to receive grants to start a business (Fryges et al., 2011, p. 15). On the contrary, OTEA are usually associated with larger companies, higher turnover by generating higher incomes (Hechavarria \& Reynolds, 2009; Block \& Wagner, 2010), which improves their position as borrowers, having to face fewer obstacles to access bank credit, therefore being more dependent on monetary policy.

At the same time, fiscal policy is a key tool for entrepreneurial activity (Djankov et al., 2010; Harju \& Kosonen, 2012). In keeping with a Keynesian approach (1936), it can be 
argued that government intervention in the form of the implementation of an expansive fiscal policy will stimulate aggregate demand and business activity (Cullen \& Gordon, 2007; Arnold et al., 2011; Cumming \& Li, 2013). However, the negative effect of a restrictive fiscal policy may be greater for NTEA. A tax increase affects the willingness to take risks (Gemmell et al., 2011; Arnold et al., 2011), the risks associated with starting a business is higher for entrepreneurs by necessity than for entrepreneurs by opportunity.

Researchers have argued that the business start-up decisions are shaped by predominant values within the social and cultural context in which they are embedded (Hayton et al., 2002; Pinillos \& Reyes, 2011). Within these types of factors, governance plays a fundamental role because the creation of new companies requires certain political, social, and economic conditions (Van de Ven, 1993). That is, effective governance is related to positive intent to engage in entrepreneurship. Trust in government effectiveness is related to citizens' willingness to take risks associated with investing, starting and managing new businesses (Friedman, 2011, p. 221). Governance affects both NTEA and OTEA. However, taking into account the wide variety of indicators that have been designed to define the governance and that each type of entrepreneurship has its own unique characteristics, these indicators may affect NTEA and OTEA differently.

Likewise, we need to consider human capital. According to Becker (1964), human capital can be defined as the skills and knowledge that individuals acquire through investments in education, on-the-job training, and other types of experience.

Necessity-driven entrepreneurs are more likely to be located in lower income regions, so they are likely to have limited access to human capital (Hessel et al., 2008). Since they do not have a high level of education, it is important for them to be able to recognize that they possess the knowledge and skills necessary to be an entrepreneur ${ }^{2}$ (Peña et al., 2014), it is crucial that they perceive their own abilities as key to the success of their business (Kahneman \& Lovallo, 1994). This is because the level of education does not necessarily imply a significant impact on the preferences to become an entrepreneur (Grilo \& Irigoyen, 2006), it is relatively more important to have certain non-cognitive skills, such as social skill (Baron \& Markman, 2003) or creativity (Weitzel et al., 2010). In short, the increased confidence gained by the individual when he perceives that he has levels of capabilities needed, even if he does not have a high level of education, will be an incentive to become an entrepreneur when he is in an unemployment situation, compared to the more comfortable alternative to wait to find a job or receive the corresponding unemployment insurance.

Opportunity-driven entrepreneurs, on the other hand, are often characterised by high levels of education (Block \& Sandner, 2009), since higher levels of education increase the agility of the individual to identify and discover business opportunities (Diochon et al., 2008; Sánchez, 2011). However, this relationship may be over-emphasized (Baum \& Silverman, 2004), there are much more influential economic factors, such as monetary policy, fiscal policy or governance, as justified above.

\footnotetext{
${ }^{2}$ We will use the indicator "perceived capacities" to measure this dimension. This indicator is defined by the GEM as the percentage of the population aged 18-64 who believe they have the skills and knowledge required to start a business. It is considered a determinant factor of entrepreneurial activity and to be directly related to an individual's human capital.
} 
In light of all these considerations, the following hypotheses are proposed:

- H2: Fiscal policy affects necessity-driven and opportunity-driven entrepreneurship.

- H3: Monetary policy affects necessity-driven and opportunity-driven entrepreneurship.

- H4: Human capital and governance affect necessity-driven and opportunity-driven entrepreneurship.

\subsection{NTEA, OTEA and the business cycle}

The positive impact of entrepreneurship on economic growth has positioned itself as a key instrument of economic policy in many economies and plays a fundamental role in the process of recovery and growth (Acs et al., 2017). However, not only is entrepreneurship capable of affecting on the business cycle (Koellinger \& Thurik, 2012), but the existence of bi-directional causality needs to be recognised: that is, entrepreneurship both causes and is caused by business cycles (Parker et al., 2012). Motivation can be conditioned by the business cycle phase (Fairlie \& Fossen, 2018; Roche \& Conti, 2018), so the explanatory variables that foster or hamper motivation and entrepreneurial action will differ, especially if the difference between necessity-driven entrepreneurship and opportunity-driven entrepreneurship is considered.

Despite scholars who study entrepreneurship have analyzed the effect of business cycles on NTEA and OTEA (Thompson, 2011; Fritsch et al., 2016; Fairlie \& Fossen, 2018) as well as the factors influencing on NTEA and OTEA (see above) a research that integrates both elements, has not been proposed. All these studies are conducted at a high level of aggregation. This research contributes to this limitation.

Hence, the following hypothesis is proposed:

- H5: H2, H3 and H4 differ depending on the business cycle phase: expansion (20012008) or crisis and recovery (2009-2016).

\section{Methodology}

\subsection{Sample and data collection}

The empirical work was carried out using a consistent estimation method for a static linear panel data model. A panel data model includes a sample of economic agents (individuals, companies, countries, etc.) for a specified period of time, that is, it combines both types of data, temporal and structural dimension (Mayorga \& Muñoz, 2000). Applied to this research, the impact of a set of monetary, fiscal and sociocultural variables on the entrepreneurial activity for 32 countries (sufficient statistical information) in 16 years is studied, so this technique is appropriate. In addition, the use of panel data technique is especially useful since it is intended to study the individual behavior of each country to conclude which of them is more prone to entrepreneurship in each stage of the business cycle.

Data on entrepreneurial activity are from GEM, focusing on the variables OTEA and NTEA. As stated above, both of them are the most common motivations and, therefore, the most representative of TEA (Reynolds et al., 2002; Block \& Wagner, 2010). Differentiating between NTEA and OTEA, it is possible to further specify the behavior of the total entre- 
preneurial activity and, at the same time, taking into account that so far, there are very few studies focused on the impact that economic and sociocultural factors have on NTEA and OTEA (Hessels et al., 2008; Giacomin et al., 2011) depending on the country and the business cycle, will contribute to overcome this limitation.

For each type of entrepreneurship, two different periods were considered: 2001-2008 (expansion) and 2009-2016 (crisis and recovery). This is reasonable because exploring and explaining the behaviour of NTEA and OTEA in different stages of the business cycle, it will be possible to design more efficient policies to promote TEA (as NTEA and OTEA are the main components of TEA) dealing with new situations of the business cycle.

With a view to subsequently proposing econometric models, those countries for which there was sufficient data in the GEM were selected for each exploratory model of TEA and its NTEA and OTEA analysis components (Table 1). Then, the most representative countries were selected for each type of entrepreneurship for homogeneous periods of the business cycle. This representativeness was determined by obtaining the average data for each country (interval average $+/$ - standard deviation). This would lead to obtain valid conclusions for more national economies.

Table 1. Countries considered for each of the exploratory models

\begin{tabular}{|c|c|c|}
\hline GEM & 2001-2016 & $\begin{array}{l}\text { Australia, Austria, Belgium, Brazil, Canada, Chile, China, Czech Rep., } \\
\text { Denmark, Finland, France, Germany, Greece, Hungary, Iceland, India, } \\
\text { Ireland, Israel, Italy, Japan, Luxembourg, Mexico, Netherlands, New Zealand, } \\
\text { Norway, Poland, Portugal, Slovak Rep., Slovenia, South Korea, Spain, } \\
\text { Sweden, Switzerland, UK, USA }\end{array}$ \\
\hline \multirow[b]{2}{*}{ NTEA } & 2001-2008 & $\begin{array}{l}\text { Australia, Austria, Belgium, Canada, Denmark, Finland, France, Germany, } \\
\text { Greece, Hungary, Ireland, Israel, Italy, Japan, Netherlands, Norway, Portugal, } \\
\text { Slovenia, Spain, Sweden, Switzerland, UK, USA }\end{array}$ \\
\hline & 2009-2016 & $\begin{array}{l}\text { Australia, Austria, Belgium, Canada, Czech Rep., Finland, France, Germany, } \\
\text { Greece, Hungary, India, Ireland, Israel, Italy, Japan, Mexico, Netherlands, } \\
\text { Norway, Portugal, Slovenia, South Korea, Spain, Sweden, Switzerland, UK, } \\
\text { USA }\end{array}$ \\
\hline \multirow[b]{2}{*}{ OTEA } & 2001-2008 & $\begin{array}{l}\text { Denmark, Finland, Greece, Hungary, India, Israel, Italy, Japan, Mexico, } \\
\text { Netherlands, Slovenia, Spain, Sweden, Switzerland, UK }\end{array}$ \\
\hline & 2009-2016 & $\begin{array}{l}\text { Austria, Belgium, China, Czech Rep., Denmark, Finland, France, Germany, } \\
\text { Greece, Hungary, India, Ireland, Israel, Japan, Mexico, Netherlands, Norway, } \\
\text { Poland, Portugal, Slovenia, South Korea, Sweden, Switzerland, UK }\end{array}$ \\
\hline \multirow[b]{2}{*}{ TEA } & 2001-2008 & $\begin{array}{l}\text { Canada, Denmark, Finland, France, Germany, Greece, Hungary, Ireland, } \\
\text { Israel, Italy, Mexico, Netherlands, Norway, Poland, Portugal, Slovenia, Spain, } \\
\text { Switzerland, UK, USA }\end{array}$ \\
\hline & 2009-2016 & $\begin{array}{l}\text { Australia, Austria, Belgium, Czech Rep., Denmark, Finland, France, } \\
\text { Germany, Greece, Hungary, India, Ireland, Israel, Netherlands, Norway, } \\
\text { Poland, Portugal, Slovenia, South Korea, Spain, Sweden, Switzerland, UK, } \\
\text { USA }\end{array}$ \\
\hline
\end{tabular}

Second, the proxy variables for the economic factors (monetary policy and fiscal policy) and social factors (human capital and governance) (with sufficient data) were collected, as explained in the literature review above (Table 2). 
Table 2. Proxy variables (initial) for the socioeconomic factors affecting TEA

\begin{tabular}{|c|c|c|c|}
\hline & Variable & Concept & Database \\
\hline \multirow{3}{*}{$\begin{array}{l}\text { Entre- } \\
\text { preneur }\end{array}$} & NTEA & $\begin{array}{l}\text { Necessity-Driven Early-Stage Entrepreneur } \\
(\% \text { TEA) }\end{array}$ & \multirow{3}{*}{ GEM } \\
\hline & OTEA & $\begin{array}{l}\text { Opportunity-Driven Early-Stage Entrepreneur } \\
\text { (\% TEA) }\end{array}$ & \\
\hline & TEA & Total Early-Stage Entrepreneurial Activity (\%) & \\
\hline GDP & GDPPC & GDP per Capita (US\$ current prices) & \multirow{2}{*}{ World Bank } \\
\hline \multirow{3}{*}{$\begin{array}{l}\text { Monetary } \\
\text { policy }\end{array}$} & CRED & Internal credit to the private sector (\% GDP) & \\
\hline & IR & Central bank interest rate $(\%)$ & \multirow{4}{*}{ Datosmacro.com } \\
\hline & FIN & $\begin{array}{l}\text { Financing for entrepreneurs (including grants } \\
\text { and subsidies) }\end{array}$ & \\
\hline \multirow{3}{*}{$\begin{array}{l}\text { Fiscal } \\
\text { policy }\end{array}$} & PEM & Public expenditure (million euros) & \\
\hline & PEG & Public expenditure (\% GDP) & \\
\hline & TAX & Tax burden (\% of GDP) & $\begin{array}{l}\text { Index of Economic } \\
\text { Freedom (Heritage } \\
\text { Foundation })^{3}\end{array}$ \\
\hline \multirow{6}{*}{$\begin{array}{l}\text { Human } \\
\text { capital }\end{array}$} & PEET & Public Expenditure Education (\% Total PE) & Datosmacro.com \\
\hline & PEEG & Public Expenditure Education (\% GDP) & \multirow{2}{*}{ UNESCO } \\
\hline & TERED & Tertiary Education & \\
\hline & CAP & Perceived Capabilities & \multirow{3}{*}{ GEM } \\
\hline & BASED & Basic Education & \\
\hline & POSTED & Posterior Education & \\
\hline \multirow{11}{*}{$\begin{array}{l}\text { Gover- } \\
\text { nance }\end{array}$} & GOVINT & Government Integrity & \multirow{8}{*}{$\begin{array}{l}\text { The Index of } \\
\text { Economic Free- } \\
\text { dom (Heritage } \\
\text { Foundation) }\end{array}$} \\
\hline & $\mathrm{BF}$ & Business Freedom & \\
\hline & LF & Labor Freedom & \\
\hline & MF & Monetary Freedom & \\
\hline & $\mathrm{TF}$ & Trade Freedom & \\
\hline & IF & Investment Freedom & \\
\hline & FF & Financial Freedom & \\
\hline & RLAW & Rule of Law & \\
\hline & REGQ & Regulation Quality & \multirow{3}{*}{$\begin{array}{l}\text { World Bank (World- } \\
\text { wide Governance } \\
\text { Indicator) }\end{array}$} \\
\hline & GOVEF & Government Effectiveness & \\
\hline & PSAV & Political Stability and Absence of Violence & \\
\hline \multirow{3}{*}{ Emp } & UNEMP & Unemployment, Total (\%) & \multirow{3}{*}{ World Bank } \\
\hline & ACTP & Active Population & \\
\hline & EMP & Employment & \\
\hline
\end{tabular}

\footnotetext{
${ }^{3}$ The Index of Economic Freedom (IEF) is an indicator developed by the Worldwide Governance Indicators (WGI) project (Kaufmann et al., 2014) for the World Bank. It measures 12 quantitative and qualitative factors representative of economic freedom grouped into 4 categories: rule of law (property rights, government integrity, judicial effectiveness), government size (government spending, tax burden, fiscal health), regulatory efficiency (business freedom, labor freedom, monetary freedom), and open markets (trade freedom, investment freedom, financial freedom). For this study, the factors most representative of entrepreneurship were selected.
} 


\section{Results}

The empirical analysis is composed by six regression models. Their specification and objectives are shown in Table 3.

Table 3. Specification and objectives of empirical research

\begin{tabular}{|c|c|c|c|}
\hline \multicolumn{2}{|c|}{ Especification } & \multicolumn{2}{|c|}{ Objectives } \\
\hline TEA = $\mathrm{f}(\mathrm{NTEA}, \mathrm{OTEA})$ & $\begin{array}{l}\text { M1 (2001-2008) } \\
\text { M2 (2009-2016) }\end{array}$ & $\begin{array}{l}\text { Representativeness of } \\
\text { NTEA and OTEA in TEA } \\
\text { in each stage }\end{array}$ & \multirow{3}{*}{$\begin{array}{l}\text { Design of more } \\
\text { efficient policies for } \\
\text { the promotion of } \\
\text { entrepreneurship in } \\
\text { each stage }\end{array}$} \\
\hline $\begin{array}{l}\text { NTEA }=\mathrm{f} \text { (economic and } \\
\text { sociocultural factors) }\end{array}$ & $\begin{array}{l}\text { M3 (2001-2008) } \\
\text { M4 (2009-2016) }\end{array}$ & \multirow{2}{*}{$\begin{array}{l}\text { Determining factors of } \\
\text { NTEA and OTEA in each } \\
\text { stage }\end{array}$} & \\
\hline $\begin{array}{l}\mathrm{OTEA}=\mathrm{f} \text { (economic and } \\
\text { sociocultural factors) }\end{array}$ & $\begin{array}{l}\text { M5 (2001-2008) } \\
\text { M6 (2009-2016) }\end{array}$ & & \\
\hline
\end{tabular}

Panel data regressions were run to test the hypotheses. The regression model results are shown in Tables 3, 4, and 5.

Table 4. Exploratory explanatory models of TEA by NTEA and OTEA component

\begin{tabular}{|c|c|c|}
\hline Dependent variable: TEA & Model 1 (M1) (2001-2008) & Model 2 (M2) (2009-2016) \\
\hline $\begin{array}{l}\text { Independent variables } \\
\text { (significant and uncorrelated) }\end{array}$ & $\begin{array}{l}\text { NTEA }(+)^{* * *} \\
\text { OTEA }(+)^{* * *}\end{array}$ & $\begin{array}{l}\text { NTEA }(+)^{* * *} \\
\text { OTEA }(+)^{* * *}\end{array}$ \\
\hline Coefficients & $\begin{array}{l}\text { NTEA: } 1.193327 \\
\text { OTEA: } 1.079397\end{array}$ & $\begin{array}{l}\text { NTEA: } 1.056157 \\
\text { OTEA: } 1.175731\end{array}$ \\
\hline Standardized coefficients $\left(\beta^{\star}\right)^{4}$ & $\begin{array}{l}\text { NTEA: } 0.361273 \\
\text { OTEA: } 0.655658\end{array}$ & $\begin{array}{l}\text { NTEA: } 0.392887 \\
\text { OTEA: } 0.82077\end{array}$ \\
\hline $\mathrm{R}^{2}$-adjusted & 0.8979 & 0.8470 \\
\hline Estimation (Hausman Test) & FE & $\mathrm{RE}$ \\
\hline $\mathrm{N}$ (groups) & 66 (20 groups) & 158 (24 groups) \\
\hline
\end{tabular}

Note: ${ }^{\star} P \geq 0.9 ;{ }^{* *} P \geq 0.95 ;{ }^{* *} P \geq 0.99$.

First, M1 and M2 (Table 4) are exploratory econometric models of total entrepreneurial activity (TEA). According to the results, the two main components of TEA are necessity and opportunity (De la Vega, 2008). These models suggest that it is valid ( $P \geq 0.99)$ to study and analyze TEA through the two main TEA components considered (NTEA and OTEA), both in expansion $\left(\beta_{\text {NTEA } / T E A}^{*}=0.361, \beta_{O T E A / T E A}^{*}=0.656\right)$ and crisis and subsequent recovery $\left(\beta_{\text {NTEA } / T E A}^{*}=0.393, \beta_{\text {OTEA } / T E A}^{*}=0.821\right)$ phases. Therefore, by studying the behavior of both, fully valid and significant conclusions can be reached regarding TEA without the need to study other forms of entrepreneurship. Accordingly, H1 is supported. The results are con-

\footnotetext{
${ }^{4}$ The standardized coefficients obtained in the six models are not an output of Stata software. The standardized coefficients have been calculated directly from the unstandardized coefficients along with the standard deviations of the variables involved: $\hat{\beta}_{j}^{*}=\hat{\beta}_{j} \times \frac{S D\left(x_{j}\right)}{S D(y)}$.
} 
sistent with that in the existing research (Reynolds et al., 2002; De la Vega, 2008; Block \& Wagner, 2010).

Additionally, the value of the standardized coefficients obtained in both periods makes it possible to conclude that OTEA explains TEA behavior to a greater extent than NTEA $\left(\beta_{\text {OTEA } / T E A}^{*}=0.655>\beta_{\text {NTEA } / T E A}^{*}=0.361 ; \beta_{\text {OTEA } / T E A}^{*}=0.820>\beta_{N T E A / T E A}^{*}=0.392\right)$ and that it is even more relevant in the period 2009-2016 $\left(\beta_{\text {OTEA } / \text { TEA }}^{*}=0.821>\beta_{\text {OTEA } / \text { TEA }}^{*}=0.656\right)$. This finding is consistent with the GEM's assertion that, although economies with a high GDP show lower levels of TEA, a greater proportion of this activity corresponds to opportunitydriven ventures (Xavier et al., 2013, p. 7).

The Hausman test was used to determine the most appropriate estimation method - fixed effects (FE) or random effects (RE) - in order to obtain the most robust parameters in each case. In the case of FE estimation, the individual effects offered interesting information about the countries that most resemble the behavior described by the model concerned. A country whose individual effect is closer to zero will have minimal heterogeneity with regard to the model. This means that the model is very representative for that country and, therefore, implies that the entrepreneurship promotion policies that are designed will be more efficient.

The model 1 (2001-2008) was estimated with FE. The individual effects obtained are represented in $y$-axis in Figure 2. The dashed line (interval average $+/-$ standard deviation) allow to delimit the countries for which the model is representative. Therefore, it can be concluded that this model is representative for 16 of the 20 countries included in the estimation. In addition, the model will be more representative for those countries whose value of their individual effects are closer to zero.

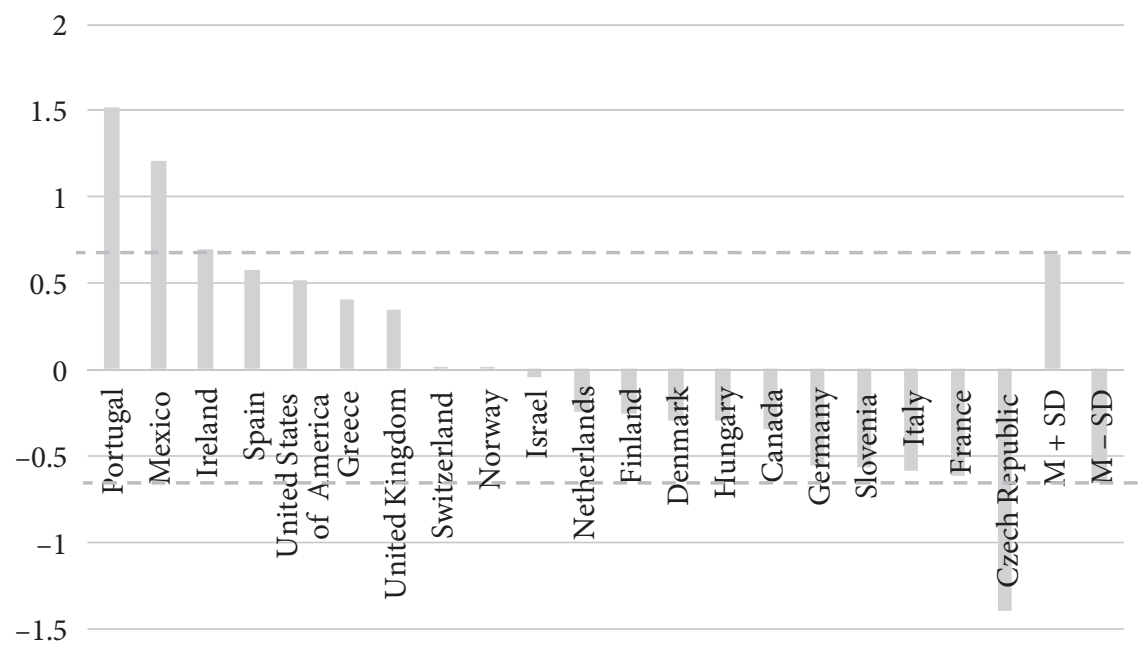

Figure 2. Individual effects for the TEA exploratory model (2001-2008)

Next, exploratory models of the behavior of NTEA were proposed. As in the previous case, the effect of the business cycle phase - expansion (2001-2008) or crisis and beginning of recovery (2009-2016) - was analyzed (Table 5).

Economic and socio-cultural factors affect NTEA in the two phases of the economic cycle. Fiscal policy, represented by the tax burden (TAX), was decisive in both considered 
periods (2001-2008 and 2009-2016) but the signs vary. TAX affected NTEA inversely in the expansion period (2001-2008) and directly in the crisis and recovery period (2009-2016). With regard to governance, as represented by government integrity (GOVINT), exerts a negative influence in times of crisis and at the start of recovery (2009-2016). Finally, the human capital, represented by perceived capabilities (CAP) exerts a positive influence during the expansion period (2001-2008). The interpretation of the standardized coefficients makes it possible to conclude which factors explain the behaviour of NTEA for each established period to the greatest extent. While during the expansion period (2001-2008) human capital (CAP) has a greater impact, the fiscal policy (TAX) has the greatest impact during times of crisis and at the start of recovery (2009-2016) (Table 5, Model 3).

Table 5. Explanatory exploratory models of TEA by NTEA component

\begin{tabular}{|c|c|c|}
\hline Dependent variable: TEA & Model 3 (M3) (2001-2008) & Model 4 (M4) (2009-2016) \\
\hline $\begin{array}{l}\text { Independent variables } \\
\text { (significant and uncorrelated) }\end{array}$ & $\begin{array}{l}\operatorname{TAX}(-)^{* *} \\
\operatorname{CAP}(+)^{* * *}\end{array}$ & $\begin{array}{c}\text { TAX }(+)^{* * *} \\
\operatorname{GOVINT}(-)^{* * *}\end{array}$ \\
\hline Coefficients & $\begin{array}{l}\text { TAX: }-0.204512 \\
\text { CAP: } 0.0317906\end{array}$ & $\begin{array}{c}\text { TAX: } 0.306205 \\
\text { GOVINT: }-0.014738\end{array}$ \\
\hline Standardized coefficients $\left(\beta^{\star}\right)$ & $\begin{array}{l}\text { TAX: }-0.42867 \\
\text { CAP: } 0.58337\end{array}$ & $\begin{array}{c}\text { TAX: } 0.4404 \\
\text { GOVINT: }-0.3387\end{array}$ \\
\hline $\mathrm{R}^{2}$-adjusted & 0.006 & 0.4397 \\
\hline Estimation (Hausman Test) & $\mathrm{FE}$ & $\mathrm{RE}$ \\
\hline $\mathrm{N}$ (groups) & 152 (23 groups) & 150 (26 groups) \\
\hline
\end{tabular}

Note: ${ }^{\star} P \geq 0.9 ;{ }^{* *} P \geq 0.95 ;{ }^{* *} P \geq 0.99$.

The NTEA exploratory model was estimated with FE in the expansion phase (Table 5, Model 3). Thus, the individual effects (represented in y-axis of Figure 3) offer interesting additional information about the countries in which the estimate obtained was most representative for the period 2001-2008. Therefore, it can be concluded that this model is representative for 16 of the 20 countries included in the estimation. Furthermore, the model will be more representative for those whose individual effects are closer to zero (Figure 3).

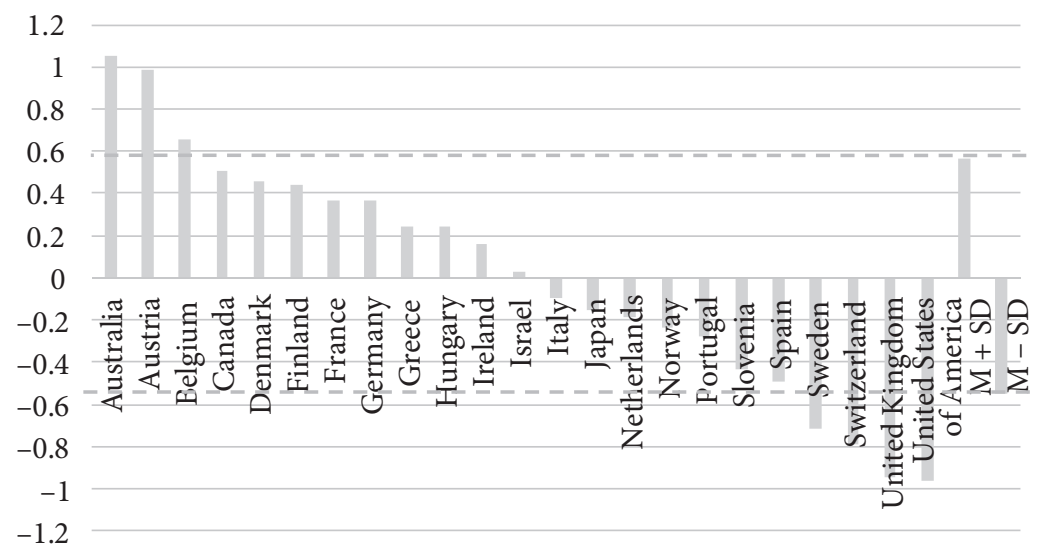

Figure 3. Individual effects for the NTEA exploratory model (2001-2008) 
Finally, exploratory model of the behavior of OTEA were proposed. As in the previous case, the effect of the business cycle phase - expansion (2001-2008) or crisis and beginning of recovery (2009-2016) - was analyzed (Table 6).

Table 6. Explanatory exploratory models of TEA by OTEA component

\begin{tabular}{|l|c|c|}
\hline \multicolumn{1}{|c|}{ Dependent variable: OTEA } & Model 5 (M5) (2001-2008) & Model 6 (M6) (2009-2016) \\
\hline $\begin{array}{l}\text { Independent variables } \\
\text { (significant and uncorrelated) }\end{array}$ & TAX $(+)^{* * *}$ & IR $(-)^{* * *}$ \\
REGQ $(-)^{* * *}$ & TF $(+)^{* *}$ \\
\hline GOVINT $(+)^{* *}$ & IR: -0.346143 \\
& TAX: 0.107556 & REGQ: 0.104731 \\
& GOVINT: 0.060499 & TF: 0.152264 \\
\hline Standardized coefficients $\left(\beta^{*}\right)$ & TAX: 0.793 & REGQ: 1.158 \\
& GOVINT: 0.805 & TF: 0.679 \\
\hline $\mathrm{R}^{2}$-adjusted & 0.049 & 0.041 \\
\hline Estimation $($ Hausman Test $)$ & RE & FE \\
\hline $\mathrm{N}$ (groups) & $57(19$ groups $)$ & $143(24$ groups $)$ \\
\hline
\end{tabular}

Note: ${ }^{\star} P \geq 0.9 ;{ }^{*} P \geq 0.95 ;{ }^{* *} P \geq 0.99$.

Economic and socio-cultural factors affect OTEA during the whole period. Fiscal policy, represented by the tax burden (TAX), was only decisive in the expansion period (2001-2008) and the relation was positive. With regard to governance, as represented by government integrity (GOVINT), regulation quality (REGQ) and trade freedom (TF), it is a coincident factor for both periods, although the sing varies. GOVINT and TF are directly related during the expansion period (2001-2008) and times of crisis and at the start of recovery (2009-2016), respectively. REGQ and OTEA are inversely related during 2009-2016 period. The interpretation of the standardized coefficients makes it possible to conclude which socioeconomic factors explain the behavior of OTEA for each established period to the greatest extent. During the expansion period (2001-2008), although governance and fiscal policy has a very similar impact on OTEA, the governance (represented by GOVINT) impact is greater. This governance (TF, REGQ) relevance is repeated during times of crisis and the start of recovery (2009-2016).

The FE applied to estimate the OTEA exploratory models for the 2009-2016 period (Table 6, Model 6) made it possible to analyze the individual effects (represented in y-axis of Figure 4). In this case, this model is representative for 21 of the 24 countries included in the estimation, being more representative for those whose individual effects are closer to zero.

The last four models (M3, M4, M5 and M6) suggest that economic $\left(\beta_{T A X}^{*}=-0.428, P \geq 0.95\right.$; $\left.\beta_{\text {TAX }}^{*}=0.440, P \geq 0.99 ; \quad \beta_{\text {TAX }}^{*}=0.793, P \geq 0.99 ; \quad \beta_{I R}^{*}=-0.488, P \geq 0.99\right)$ and socio-cultural factors $\quad\left(\beta_{C A P}^{*}=0.583, P \leq 0.05 ; \quad \beta_{G O V I N T}^{*}=-0.338, P \leq 0.05 ; \quad \beta_{G O V I N T}^{*}=0.805, P \leq 0.05\right.$; $\left.\beta_{R E G Q}^{*}=1.152, P \leq 0.05 ; \quad \beta_{T F}^{*}=0.697, P \leq 0.05\right)$ exert a significant influence on the behavior of entrepreneurs. They show that the explanatory factors NTEA and OTEA are different, and, also, that they vary depending on the business cycle phase. Therefore, the data supports 


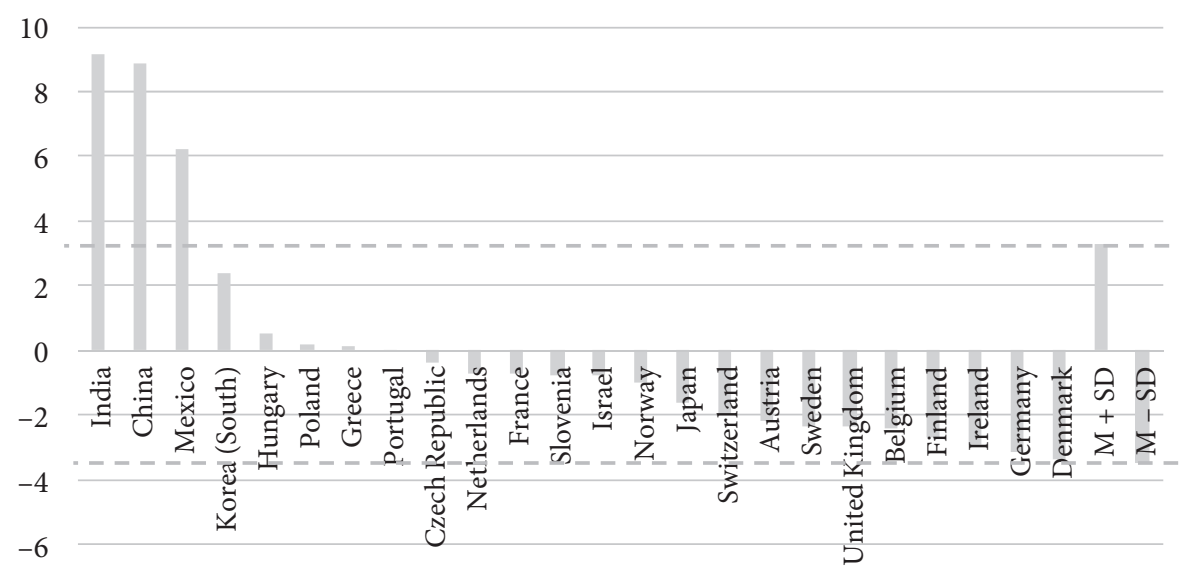

Figure 4. Individual effects for the OTEA exploratory model (2009-2016)

H2, H3, H4, H5. The R2 of Model 3, Model 5 and Model 6 were small. This is because many other factors also influence the opportunity and necessity entrepreneur variables.

The results obtained for the models are consistent with the existing literature (given in Section 1). The results thus support a reliable and valid measurement instrument.

\section{Discussion and policy implications}

The results of the analysis support all the hypotheses. According to the results of Model 1 and Model 2, the two main components of TEA are necessity and opportunity which confirms the theoretical arguments describe in Section 1 (Reynolds et al., 2002; De la Vega, 2008; Block \& Wagner, 2010).

These findings have the following policy implications.

First, in both of the periods considered, OTEA contributes more than NTEA to the generation of TEA, and that it is even more relevant in the period 2009-2016 (Table 4). Therefore, economic policies should encourage OTEA in order to promote the development of TEA, thereby generating economic growth.

Second, it is possible to define the most effective policies to stimulate entrepreneurship through the promotion of NTEA and OTEA in both periods considered (2001-2008 and 2009-2016).

On the one hand, the following policies should be defined in periods of expansion (20012008).

For the promotion of NTEA, the implementation of expansive fiscal policies with reductions of the tax burden (TAX) should be used, Necessity-driven entrepreneurs usually have less access to bank financing; they will thus prioritize alternative sources of financing, such as public subsidies (Fryges et al., 2011). Therefore, fiscal policy is a key tool for this type of entrepreneurship. Additionally, one of the most important features of entrepreneurship is entrepreneurs' recognition that they possess the knowledge and skills needed to start a business (CAP) (Peña et al., 2014). This is because it increases their self-confidence and likeli- 
hood of success (Kahneman \& Lovallo, 1994), which in turn reduces risk aversion, which is especially acute among necessity-driven entrepeneurs. Accordingly, the implementation of public policies focused on improving education could be a good measure to promote NTEA in periods of crisis (Table 5. Model 3). This finding is consistent with the opinion of political leaders who argue that entrepreneurship and higher-education policies should be considered in tandem (Millán et al., 2014). This model is representative for 16 of the 20 countries included in the estimation (Figure 3), therefore these policies constitute a useful reference for developed countries.

For the promotion of OTEA, the quality of governance should be improved, for example, by optimizing government integrity (GOVINT). Furthermore, the direct relationship between TAX and OTEA shows that a potential tax increase would not negatively affect that type of entrepreneurship, because such entrepreneurs have sufficient resources and access to new financing to assume greater tax obligations (Table 6. Model 5).

Governments should consider which type of entrepreneurship it would be most beneficial to incentivize and not only to increase entrepreneurship indiscriminately (Angulo-Guerrero et al., 2017). In expansion periods, in which business opportunities are more frequent and numerous, OTEA is more likely to be the most common.

On the other hand, the following policies should be defined in the crisis phase and at the start of recovery periods (2009-2016).

The direct relationship between NTEA and TAX in the crisis phase and at the start of recovery periods (2009-2016) underscores the advisability of implementing expansive fiscal policies that do not create undue tax burdens for entrepreneurs who have no choice but to start a business due to the lack of alternative employment and low income. Additionally, governance has an indirect effect, meaning that the weaker GOVINT is, the higher the levels of necessity-driven entrepreneurship will be, undertaken by individuals whose employment and wealth levels are suffering, especially, those who were already at low-income levels to begin with (Table 5 . Model 3).

In contrast, if the aim is to encourage OTEA, then the implementation of expansive monetary policies, through reductions in interest rates (IR), would be the most efficient. This is corroborated by the fact that opportunity-driven entrepreneurs have easy access to financing dependent on interest rates, such as bank credit (Block \& Wagner, 2010). If these results are considered along with the results obtained in 2001-2008, it possible to conclude the importance of monetary policy compared with fiscal policy for this type of entrepreneurship. Alternatively, it could also act by improving the quality of governance, in this case, by optimizing regulation quality (REGQ) and/or trade freedom (TF). These results are consistent with the considerations of Clark et al. (2018) by finding that foreign market entry as a growth opportunity (Table 6. Model 6). This model is representative for 21 of the 24 countries included in the estimation (Figure 4), therefore these policies constitute a useful reference for developed countries.

As in the previous case, although these are different measures, the government should consider which type of entrepreneurship it should incentivize. In the case of a crisis and at the beginning of recovery periods, NTEA is more likely to be the most frequent type of entrepreneurship, since in this phase of the cycle, unemployment levels are higher and business opportunities are less frequent and numerous. 
Finally, the values of the standardized coefficients suggest that the most effective factors to influence to incentivize NTEA are CAP (expansion) and TAX (crisis and recovery). In contrast, the most effective factor to encourage OTEA is governance, both during growth (GOVINT) and crisis (REGQ, TF) phases. These results all are present in Table 7.

Table 7. Summary of results obtained: determinant factors and standardized coefficients

\begin{tabular}{|c|c|c|c|c|c|c|}
\hline & & $\begin{array}{l}\text { Fiscal } \\
\text { policy }\end{array}$ & $\begin{array}{l}\text { Mone- } \\
\text { tary } \\
\text { policy }\end{array}$ & $\begin{array}{l}\text { Socio-cultural } \\
\text { factors }\end{array}$ & Policies & Countries \\
\hline \multirow[t]{2}{*}{ 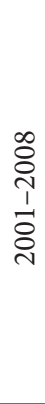 } & 空 & $\begin{array}{c}\text { TAX }(-) \\
\beta^{*}= \\
-0.428\end{array}$ & & $\begin{array}{c}\mathrm{CAP}(++) \\
\beta^{*}=+0.583\end{array}$ & $\begin{array}{l}\text { - Expansive fiscal policies: } \\
\text { reductions of the tax } \\
\text { burden (TAX). } \\
\text { - Improving education } \\
\text { (CAP). }\end{array}$ & $\begin{array}{l}\text { Canada, Denmark, } \\
\text { Finland, France, } \\
\text { Germany, Greece, } \\
\text { Hungary, Ireland, Israel, } \\
\text { Italy, Japan, Netherlands, } \\
\text { Norway, Portugal, } \\
\text { Slovenia, Spain. }\end{array}$ \\
\hline & 楸 & $\begin{array}{c}\operatorname{TAX}(+) \\
\beta^{\star}= \\
+0.793\end{array}$ & & $\begin{array}{c}\text { GOVINT }(++) \\
\beta^{*}=+0.805\end{array}$ & $\begin{array}{l}\text { - Improving the quality } \\
\text { of governance: by } \\
\text { optimizing government } \\
\text { integrity (GOVINT). }\end{array}$ & $\begin{array}{l}\text { Random Effects. Not } \\
\text { individual effects. }\end{array}$ \\
\hline \multirow[b]{2}{*}{ 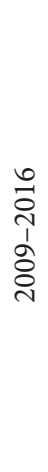 } & $\begin{array}{l}\text { 壵 } \\
\text { 乙 } \\
\text { 乙 }\end{array}$ & $\begin{array}{c}\text { TAX }(++) \\
\beta^{*}= \\
+0.440\end{array}$ & & $\begin{array}{l}\text { GOVINT }(-) \\
\beta^{*}=-0.338\end{array}$ & $\begin{array}{l}\text { - Expansive fiscal policies: } \\
\text { not create undue tax } \\
\text { burdens for NTEA } \\
\text { (TAX). }\end{array}$ & $\begin{array}{l}\text { Random Effects. } \\
\text { Not individual effects. }\end{array}$ \\
\hline & 孚 & & IR (-) & $\begin{array}{l}\text { REGQ }(--) \\
\beta^{*}=+1.152 \\
\text { TF }(+) \\
\beta^{*}=+0.679\end{array}$ & $\begin{array}{l}\text { - Expansive monetary } \\
\text { policies: reductions in } \\
\text { interest rates (IR). } \\
\text { - Improving the quality } \\
\text { of governance: by } \\
\text { optimizing regulation } \\
\text { quality (REGQ) and/or } \\
\text { trade freedom (TF). }\end{array}$ & $\begin{array}{l}\text { Austria, Belgium, Czech } \\
\text { Rep., Denmark, Finland, } \\
\text { France, Germany, } \\
\text { Greece, Hungary, } \\
\text { Ireland, Israel, Japan, } \\
\text { Netherlands, Norway, } \\
\text { Poland, Portugal, Slove- } \\
\text { nia, South Korea, Swe- } \\
\text { den, Switzerland, UK. }\end{array}$ \\
\hline
\end{tabular}

Note: $(+)$ : direct effect and medium representativity of the factor; $(++)$ : direct effect and high representativity of the factor; (-): inverse effect and medium representativity of the factor; (- - ): inverse effect and high representativity of the factor.

The research contributes to the extant literature from four directions. Firstly, it is shown that necessity and opportunity are the most frequent forms of entrepreneurship (Reynolds et al., 2002; Block \& Wagner, 2010). Secondly, it is analysed how OTEA contributes more than NTEA to the generation of TEA (Xavier et al., 2013). Thirdly, it has been studied in detail that economic and financial factors are not the only ones that influence entrepreneurial activity; social and cultural factors of the environment also significantly influence entrepreneurs' behavior (Shapero \& Sokol, 1982; Gnyawali \& Fogel, 1994; Thornton et al., 2011). This influence has been demonstrated in 32 different countries and in different stages of the business cycle. Fourth, it is shown that entrepreneurship both causes and is caused by business cycles (Parker et al., 2012). In the view of current studies, there is a lack of empirical research on entrepreneurialism based on an integrative framework enabling the design, 
preparation and implementation of more specific and more effective policies for the promotion of entrepreneurship and thus contribute to the growth of more developed economies. The investigation enriches current research by specifying the Total Entrepreneurship Activity (TEA) by analyzing the opportunity-driven and necessity-driven entrepreneurship behaviour in a disaggregated way integrating economic and sociocultural factors that affect them during different phases of the business cycle. This provides empirical evidence for political decision making. The political decision making is made possible by selecting the most representative countries for each type of entrepreneurship (necessity and opportunity) and dividing the study into homogeneous periods of the business cycle (2001-2008 and 2009-2016). All the proposed models are valid and representative for most of the countries analysed, so the policies that have been proposed in this section may serve as references for other countries in order to know how to respond appropriately to different stages of the business cycle.

\section{Conclusions and limitations of the research}

This paper has explored and examined the behavior of entrepreneurial activity in 32 national economies, considering the economic and socio-cultural drivers of necessity and opportunity entrepreneurship depending on the business cycle phase for a correct design of policies aimed at promoting entrepreneurship. Our empirical analysis results find support for our theoretical arguments set out and have great implications for the design and implementation of more specific and more effective policies for the promotion of entrepreneurship and to contribute to the growth of more developed economies. This is possible through the disaggregated analysis of the total entrepreneurship activity into its main components, i.e., necessity and opportunity and the division into homogeneous periods of the business cycle. In addition, all the proposed models are valid and representative for most of the countries analysed, so the policies proposed may serve as references for other countries in order to know how to respond appropriately to different stages of the business cycle. On the one hand, in periods of expansion (2001-2008) expansive fiscal policies with reductions of the tax burden and improvements in education should be implemented for the promotion of NTEA. Furthermore, it is possible to state that human capital is the most effective factor in this stage of the business cycle. Such policies are representative for 16 of the 20 countries included in the estimation. Alternatively, for the promotion of OTEA, the government integrity should be optimized. On the other hand, in the crisis phase and at the start of recovery periods (2009-2016), the results show that for the promotion of NTEA, expansive fiscal policies that do not create undue tax burdens for entrepreneurs who have no choice but to start a business due to the lack of alternative employment and low income should be implemented. Alternatively, for the promotion of OTEA, the government should implement expansive monetary policies, through reductions in interest rates. This reflects the importance of monetary policy compared with fiscal policy for this type of entrepreneurship. Furthermore, it could also act by optimizing regulation quality and/ or trade freedom. In this case, the most effective factor to encourage OTEA is governance, both during growth and crisis phases. Such policies are representative for 21 of the 24 countries included in the estimation. 
The empirical work had certain limitations. For instance, the data are not homogeneous due to the lack of statistical information for many of the years and countries considered in the selected databases, especially when the analysis is conducted for multiple countries as in the present case. When GEM presents the homogenized data without statistical gaps, the resulting conclusions will be more solvent and closer to reality.

Notwithstanding its limitations, the present research opens avenues of future research. First, the empirical analysis aimed to provide an adequate and effective methodology for studying entrepreneurial activity, both in terms of the technique used, which is valid for all countries worldwide, and through the selection of the most representative countries for each type of entrepreneurship, so as to prevent distortions when working with countries with atypical behaviors (outside the range mean $\pm \mathrm{SD}$ ). Second, analyzing entrepreneurial behavior by levels divided into homogeneous periods makes it possible to use the results for decision-making by designing more effective economic policy measures to achieve the objective of promoting entrepreneurship and, with it, economic growth. TEA behavior could thus be further specified. At the same time, given the scant literature to date focused on the impact of socioeconomic factors on necessity- or opportunity-driven entrepreneurship (Hessels et al., 2008; Giacomin et al., 2011), future research could seek to overcome this limitation.

\section{Acknowledgements}

The authors acknowledge and are grateful for the financial support provided by the Faculty of Law of Social Sciences of Ciudad Real (University of Castilla-La Mancha). The authors also thank to Antonio Navas, Lecturer in Economics in the Department of Economics of The University of Sheffield, for his guidance, indications and comments made to the elaboration of this article. He played a crucial role in the process of drawing up of this manuscript during a research stay carried out by two of the authors in the University of Sheffield.

\section{Funding}

This paper was funded by The University of Castilla-La Mancha.

\section{Author contributions}

All authors have contributed equally to the work and they have jointly supervised the work.

\section{Disclosure statement}

The authors declare no competing financial, professional, or personal interests from other parties. 


\section{References}

Acs, Z. J. (2006). How is entrepreneurship good for economic growth? Innovations: Technology, Governance, Globalization, 1(1), 97-107. https://doi.org/10.1162/itgg.2006.1.1.97

Acs, Z., Astebro, T., Audretsch, D., \& Robinson, D. T. (2017). Public policy to promote entrepreneurship: A call to arms. Small Business Economics, 47(1), 35-51. https://doi.org/10.1007/s11187-016-9712-2

Akinyemi, A., Oyebisi, O., \& Odot-Itoro, E. (2018). Entrepreneurship, unemployment and economic growth in Nigeria. Covenant Journal of Entrepreneurship (CJoE), 1(1), 30-46.

Amorós, J. E., \& Bosma, N. (2014). Global entrepreneurship monitor 2013. Global report: Fifteen years of assessing entrepreneurship across the globe. Babson College, Universidad del Desarrollo, UnivesitiTun Abdul Razak, and London Business School.

Angulo-Guerrero, M. J., Pérez-Moreno, S., \& Abad-Guerrero, I. M. (2017). How economic freedom affects opportunity and necessity entrepreneurship in the OECD countries. Journal of Business Research, 73, 30-37. https://doi.org/10.1016/j.jbusres.2016.11.017

Arnold, J., Brys, B., Heady, C., Johansson, A., Schwellnus, C., \& Vartia, L. (2011). Tax policy for economic recovery and growth. Economic Journal, 121(550), 59-80. https://doi.org/10.1111/j.1468-0297.2010.02415.x

Back, L. K., \& Rosen, R. J. (2011). The effect of monetary policy on the availability of credit: How the credit channel works (FRB of Chicago Working Paper, No. 2007-13 (revised)). https://doi.org/10.2139/ssrn.1066828

Baron, R., \& Markman, G. (2003). Beyond social capital: The role of entrepreneurs'social competence in their financial success. Journal of Business Venturing, 18(1), 41-60. https://doi.org/10.1016/S0883-9026(00)00069-0

Bassetto, M., Cagetti, M., \& De Nardi, M. C. (2015). Credit crunches and credit allocation in a model of entrepreneurship. Review of Economic Dynamics, 18(1), 53-76. https://doi.org/10.1016/j.red.2014.08.003

Baum, J. A. C., \& Silverman, B. S. (2004). Picking winners or building them? Alliance, intellectual, and human capital as selection criteria in venture financing and performance of biotechnology startups. Journal of Business Venturing, 19(3), 411-436. https://doi.org/10.1016/S0883-9026(03)00038-7

Becker, G. S. (1964). Human capital. University of Chicago Press.

Block, J., \& Sandner, P. (2009). Necessity and opportunity entrepreneurs and their duration in selfemployment: Evidence from German micro data. Journal of Industry, Competition and Trade, 9, 117-137. https://doi.org/10.1007/s10842-007-0029-3

Block, J., \& Wagner, M. (2010). Necessity and opportunity entrepreneurs in Germany: Characteristics and earnings differentials. Schmalenbach Business Review, 62, 154-174. https://doi.org/10.1007/BF03396803

Bonnet, J., Abdesselam, R., Renou-Maissant, P., \& Aubry, M. (2015). What happened to entrepreneurial economies after the financial crisis? An empirical study of OECD countries. In $55^{\text {th }}$ Congress of the European Regional Science Association: "World Renaissance: Changing roles for people and places", 25-28 August 2015. Lisbon, Portugal, European Regional Science Association (ERSA), Louvainla-Neuve.

Bougheas, S., Mizen, P., \& Yalcin, C. (2006). Access to external finance: Theory and evidence on the impact of monetary policy and firm-specific characteristics. Journal of Banking and Finance, 30(1), 199-227. https://doi.org/10.1016/j.jbankfin.2005.01.002

Caliendo, M., \& Kritikos, A. S. (2019). "I Want to, But I Also Need to": Start-Ups resulting from opportunity and necessity. In E. Lehmann, \& M. Keilbach (Eds.), From industrial organization to entrepreneurship (pp. 247-265). Springer, Cham. https://doi.org/10.1007/978-3-030-25237-3_23 
Carree, M. A., \& Thurik, A. R. (2003). The impact of entrepreneurship on economic growth. In D. B. Audretsch, \& Z. J. Acs (Eds.), Handbook of entrepreneurship research (pp. 437-471). Kluwer Academic. https://doi.org/10.1007/0-387-24519-7_17

Carter, N. M., Gartner, W. B., Shaver, K. G., \& Gatewood, E. J. (2003). The career reasons of nascent entrepreneurs. Journal of Business Venturing, 18(1), 13-39.

https://doi.org/10.1016/S0883-9026(02)00078-2

Cassar, G. (2007). Money, money, money? A longitudinal investigation of entrepreneur career reasons, growth preferences and achieved growth. Entrepreneurship and Regional Development, 19(1), 89-107. https://doi.org/10.1080/08985620601002246

Clark, D. R., Li, D., \& Shepherd, D. A. (2018). Country familiarity in the initial stage of foreign market selection. Journal of International Business Studies, 49(4), 442-472. https://doi.org/10.1057/s41267-017-0099-3

Cullen, J. B., \& Gordon, R. H. (2007). Taxes and entrepreneurial risk-taking: theory and evidence for the U.S. Journal of Public Economics, 91(7-8), 1479-1505. https://doi.org/10.1016/j.jpubeco.2006.12.001

Cumming, D., \& Li, D. (2013). Public policy, entrepreneurship, and venture capital in the United States. Journal of Corporate Finance, 23, 345-367. https://doi.org/10.1016/j.jcorpfin.2013.09.005

De La Vega, I. (2008). Informe Ejecutivo GEM. España: Global Entrepreneurship Monitor.

Diochon, M., Menzies, T. V., \& Gasse, Y. (2008). Exploring the nature and impact of gestation-specific human capital among nascent entrepreneurs. Journal of Developmental Entrepreneurship, 13(2), 151-165. https://doi.org/10.1142/S1084946708000909

Djankov, S., Ganser, T., Mcliesh, C., Ramalho, R., \& Shleifer, A. (2010). The effect of corporate taxes on investment and entrepreneurship. American Economic Journal: Macroeconomics, 2(3), 31-64. https://doi.org/10.1257/mac.2.3.31

Du, K., \& O'Connor, A. (2018). Entrepreneurship and advancing national level economic efficiency. Small Business Economics, 50(1), 91-111. https://doi.org/10.1007/s11187-017-9904-4

Fairlie, R. W., \& Fossen, F. (2018). Opportunity versus necessity entrepreneurship: Two components of business creation (CESifo Working Paper Series, 6854). https://doi.org/10.2139/ssrn.3132357

Fotopoulos, G., \& Storey, D. J. (2019). Public policies to enhance regional entrepreneurship: another programme failing to deliver? Small Business Economics, 53(1), 189-209. https://doi.org/10.1007/s11187-018-0021-9

Friedman, B. (2011). The relationship between governance effectiveness and entrepreneurship. International Journal of Humanities and Social Science, 1(17), 221-225.

Fritsch, M., Kritikos, A. S., \& Pijnenbug, K. (2016). The effect of the business cycle on start-ups across industries and regions - An empirical analysis for Germany. DIW Berlin and Friedrich Schiller University Jena, mimeo.

Fryges, H., Kohn, K., \& Ullrich, K. (2011). The interdependence of R\&D activity and debt financing of business start-ups (summary). Frontiers of Entrepreneurship Research, 31(3).

Gaiotti, E., \& Generale, A. (2001). Does monetary policy have asymmetric effects? A look at the investment decisions of Italian firms (Working Paper Series 110). European Central Bank.

Gemmell, N., Kneller, R., \& Sanz, I. (2011). The timing and persistence of fiscal policy impacts on growth: Evidence from OECD countries. Economic Journal, 121, 33-58. https://doi.org/10.1111/j.1468-0297.2010.02414.x

Gertler, M., \& Gilchrist, S (1994). Monetary policy, business cycles, and the behavior of small manufacturing firms. The Quarterly Journal of Economics, MIT Press, 109(2), 309-340. https://doi.org/10.2307/2118465

Giacomin, O., Janssen, F., Pruett, M., Shinnar, R. S., Llopis, F., \& Toney, B. (2011). Entrepreneurial intentions, motivations and barriers: differences among American, Asian and European students. 
International Entrepreneurship and Management Journal, 7(2), 219-238.

https://doi.org/10.1007/s11365-010-0155-y

Gnyawali, D. R., \& Fogel, D. S. (1994). Environments for entrepreneurship development: key dimensions and research implications. Entrepreneurship Theory and Practice, 18(4), 43-62.

https://doi.org/10.1177/104225879401800403

Grilo, I., \& Irigoyen, J. (2006). Entrepreneurship in the EU: To wish and not to be. Small Business Economics, 26(4), 305-318. https://doi.org/10.1007/s11187-005-1561-3

Halicioglu, F., \& Yolac, S. (2015). Testing the impact of unemployment on self-employment: Empirical evidence from OECD countries. Paper presented at the meeting of the World Conference on Technology, Innovation and Entrepreneurship. Istanbul University. https://doi.org/10.1016/j.sbspro.2015.06.161

Harju, J., \& Kosonen, T. (2012). The impact of tax incentives on the economic activity of entrepreneurs (NBER Working Paper, 18442). https://doi.org/10.3386/w18442

Hayton, J. C., George, G., \& Zahra, S. A. (2002). National culture and entrepreneurship: A review of behavioral research. Entrepreneurship Theory and Practice, 26(4), 33-52. https://doi.org/10.1177/104225870202600403

Hechavarria, D. M., \& Reynolds, P. (2009). Cultural norms and business start-ups: The impact of national values on opportunity and necessity entrepreneurs. International Entrepreneurship and Management Journal, 5(4), 417-437. https://doi.org/10.1007/s11365-009-0115-6

Hessels, S. J., Van Gelderen, M., \& Thurik, A. R. (2008). Entrepreneurial aspirations, motivations, and their drivers. Small Business Economics, 31(3), 323-339. https://doi.org/10.1007/s11187-008-9134-X

Kahneman, D., \& Lovallo, D. (1994). Timid choices and bold forecasts: A cognitive perspective on risk taking. In R. P. Rumelt, D. E. Schendel, \& D. J. Teece (Eds.), Fundamental issues in strategy: A research agenda (pp. 71-96). Harvard. Business School Press.

Kaufmann, D., Kraay, A., \& Mastruzzi, M. (2014). Worldwide government indicators. The World Bank Group.

Keynes, J. M. (1936). The general theory of employment, interest and money. MacMillan.

Koellinger, P. D., \& Thurik, A. R. (2012). Entrepreneurship and the business cycle. The Review of Economics and Statistics, 94(4), 1143-1156. https://doi.org/10.1162/REST_a_00224

Lawrenz, J., \& Oberndorfer, J. (2018). Firm size effects in trade credit supply and demand. Journal of Banking \& Finance, 93, 1-20. https://doi.org/10.1016/j.jbankfin.2018.05.014

Lucas, R. (1988). On the mechanics of economic development. Journal of Monetary Economics, 22(1), 3-42. https://doi.org/10.1016/0304-3932(88)90168-7

Ma, S., Wu, X., \& Gan, L. (2019) Credit accessibility, institutional deficiency and entrepreneurship in China. China Economic Review, 54, 160-175. https://doi.org/10.1016/j.chieco.2018.10.015

Mayorga, M., \& Muñoz, E. (2000). La técnica de datos de panel una guía para su uso e interpretación (Working paper of Central Bank of Costa Rica). Departamento de Investigaciones Económicas.

Meyer, N., \& de Jongh, J. (2018). The importance of entrepreneurship as a contributing factor to economic growth and development: The case of selected European countries. Journal of Economics and Behavioral Studies, 10(4), 287-299.

Millán, J. M., Congregado, E., \& Román, C. (2014). Entrepreneurship persistence with and without personnel: the role of human capital and previous unemployment. International Entrepreneurship and Management Journal, 10(1), 187-206. https://doi.org/10.1007/s11365-011-0184-1

Mota, A., Braga, V., \& Ratten, V. (2019). Entrepreneurship motivation: Opportunity and necessity. In V. Ratten, P. Jones, V. Braga, \& C. Marques (Eds.), Sustainable entrepreneurship. Contributions to management science. Springer, Cham. https://doi.org/10.1007/978-3-030-12342-0_8 
Noorderhaven, N., Thurik, R., Wennekers, S., \& Van Stel, A. (2004). The role of dissatisfaction and per capita income in explaining self-employment across 15 European countries. Entrepreneurship Theory and Practice, 28(5), 447-466. https://doi.org/10.1111/j.1540-6520.2004.00057.x

Pandit, D., Joshi, M. P., \& Tiwari, S. R. (2018). Examining entrepreneurial intention in higher education: An exploratory study of college students in India. The Journal of Entrepreneurship, 27(1), 25-46. https://doi.org/10.1177/0971355717738595

Parker, S. C., Congregado, E., \& Golpe, A. A. (2012). Is entrepreneurship a leading or lagging indicator of the business cycle? Evidence from UK self-employment data. International Small Business Journal: Researching Entrepreneurship, 30(7), 736-753. https://doi.org/10.1177/0266242612437560

Peña, I., Guerrero, M., \& González-Pernía, J. L. (2014). Global Entrepreneurship Monitor executive report. Informe GEM España.

Pinillos, M. J., \& Reyes, L. (2011). Relationship between individualist-collectivist culture and entrepreneurial activity: Evidence from Global Entrepreneurship Monitor data. Small Business Economics, 37(1), 23-37. https://doi.org/10.1007/s11187-009-9230-6

Poschke, M. (2013). Entrepreneurs out of necessity: A snapshot. Applied Economics Letters, 20(7), 658-663. https://doi.org/10.1080/13504851.2012.727968

Reynolds, P. D., Bygrave, W. D., Autio, E., Cox, L., \& Hay, M. (2002). Global Entrepreneurship Monitor (2002 Executive Report). Kauffman Center for Entrepreneurial Leadership.

Roche, M. P., \& Conti, A. (2018). Necessity never made a good bargain: External conditions, entrepreneurial motives, and startup outcomes. In DRUID18 Copenhagen Business School Conference (pp. 11-13). Copenhagen, Denmark.

Romer, P. M. (1986). Increasing returns and long-run growth. Journal of Political Economy, 94(5), 1002-1037. https://doi.org/10.1086/261420

Sánchez, J. C. (2011). University training for entrepreneurial competencies: Its impact on intention of venture creation. International Entrepreneurship and Management Journal, 7(2), 239-254. https://doi.org/10.1007/s11365-010-0156-x

Shapero, A., \& Sokol, L. (1982). The social dimensions of entrepreneurship. In C. Kent, D. Sexton, \& K. H. Vesper (Eds.), The encyclopedia of entrepreneurship (pp. 72-90). Prentice-Hall.

Solow, R. M. (1956). A contribution to the theory of economic growth. The Quarterly Journal of Economics, 70(1), 65-94. https://doi.org/10.2307/1884513

Swan, T. W. (1956). Economic growth and capital accumulation. Economic Record, 32(2), 334-361. https://doi.org/10.1111/j.1475-4932.1956.tb00434.x

Thompson, P. (2011). Necessity and Opportunity Entrepreneurs through the Business Cycle (Working Papers 1102). Florida International University, Department of Economics.

Thornton, P., Ribeiro-Soriano, D., \& Urbano, D. (2011). Socio-cultural factors and entrepreneurial activity: An overview. International Small Business Journal, 29(2), 1-16.

https://doi.org/10.1177/0266242610391930

Thurik, A. R., Carree, M. A., Van Stel, A. J., \& Audretsch, D. B. (2008). Does self-employment reduce unemployment? Journal of Business Venturing, 23(6), 673-686. https://doi.org/10.1016/j.jbusvent.2008.01.007

Tyszka, T., Ciéslik, J., Domurat, A., \& Macko, A. (2011). Motivation, self-efficacy, and risk attitudes among entrepreneurs during transition to a market economy. The Journal of Socio-Economics, 40(2), 124-131. https://doi.org/10.1016/j.socec.2011.01.011

Urbano, D., Aparicio, S., \& Audretsch, D. B. (2019). The effect of entrepreneurial activity on economic growth. In Institutions, entrepreneurship, and economic performance. International studies in entrepreneurship, 41. Springer, Cham. https://doi.org/10.1007/978-3-030-13373-3_4 
Urbano, D., \& Aparicio, S. (2016). Entrepreneurship capital types and economic growth: International evidence. Technological Forecasting and Social Change, 102, 34-44. https://doi.org/10.1016/j.techfore.2015.02.018

Van De Ven, A. (1993). The development of an infrastructure for entrepreneurship. Journal of Business Venturing, 8(3), 211-230. https://doi.org/10.1016/0883-9026(93)90028-4

Van Der Zwan, P., \& Hessels, J. (2013). Start-up motivation and (in) voluntary exit (EIM Business and Policy Research, Panteia/EIM Research Report (H201309)).

Walsh, J., \& Winsor, B. (2019). Socio-cultural barriers to developing a regional entrepreneurial ecosystem. Journal of Enterprising Communities: People and Places in the Global Economy, 13(3), 263-282. https://doi.org/10.1108/JEC-11-2018-0088

Weitzel, U., Urbig, D., Desai, S., Sanders, M., Y., \& Acs, Z. (2010). The good, the bad, and the talented: Entrepreneurial talent and selfish behavior. Journal of Economic Behavior \& Organization, 76(1), 64-81. https://doi.org/10.1016/j.jebo.2010.02.013

Xavier, S. R., Kelley, D., Kew, J., Herrington, M., \& Vorderwülbecke, A. (2013). GEM 2012 Global Report (Working Papers). Global Entrepreneurship Monitor. 